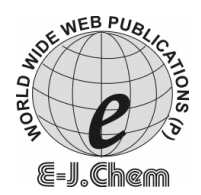

http://www.e-journals.net
ISSN: 0973-4945; CODEN ECJHAO

E-Journal of Chemistry

Vol. 5, No.4, pp. 918-923, October 2008

\title{
A Selective Bioreduction of Toxic Heavy Metal Ions from Aquatic Environment by Saccharomyces cerevisiae
}

\author{
A. M. RAHATGAONKAR* and N. R. MAHORE \\ Department of Chemistry, \\ Institute of Science, R. T. Road, Civil lines, Nagpur, India. \\ anjali_rahatgaonkar@yahoo.com
}

Received 5 April 2008; Revised 20 June 2008; Accepted 10 July 2008

\begin{abstract}
The need to remove or recover metal ions from industrial wastewater has been established in financial as well as environmental terms. This need has been proved financially in terms of cost saving through metal reuse or sale and environmentally as heavy metal toxicity can affect organisms throughout the food chain, including humans. Bioremediation of heavy metal pollution remains a major challenge in environmental biotechnology. Current removal strategies are mainly based on bioreduction of $\mathrm{Co}^{++}, \mathrm{Ni}^{++}, \mathrm{Cu}^{++}$and $\mathrm{Cd}^{++}$to their metallic forms by Saccharomyces cerevisiae in buffered aqueous solution. The rate of biotransformation was significantly influenced by $\mathrm{pH}$ of aqueous solution, concentration of biomass and hardness of water. All reaction conditions were optimized and maximum reduction of $\mathrm{Co}^{++}, \mathrm{Cd}^{++}, \mathrm{Ni}^{++}$and $\mathrm{Cu}^{++}$were observed as $80 \%, 63 \%, 50 \%$, and $44 \%$ respectively. Unreacted $\mathrm{Co}^{++}, \mathrm{Cd}^{++}, \mathrm{Ni}^{++}$metal ions were extracted by 8 -hydroxyquinoline and $\mathrm{Cu}^{++}$by diethylthio carbamate in $\mathrm{CHCl}_{3}$ at different $\mathrm{pH}$. Furthermore, the concentrations of unreacted metal ions were established spectrophotometrically.
\end{abstract}

Keywords: Saccharomyces cerevisiae, Biotransformation, Heavy metals ions, Bioreduction

\section{Introduction}

Water is regarded as the most fundamental and indispensable of all natural resources. The management of water resources is a big challenge for most countries of the world. In India, the need to recycle wastewater is increasing due to the severe shortage of fresh water. Largescale wastewater treatment constitutes a very important part of the management of water resources. In addition, heavy metals released by number of industrial processes are major pollutants in marine, ground, industrial and even treated wastewaters ${ }^{1}$. Heavy metals can be 
extremely toxic as they damage nerves, liver, kidney and bones, and also block functional groups of vital enzymes. Cobalt, nickel, chromium, cadmium and their compounds are widely used in electroplating, leather tanning, cement, dyeing, metal processing, wood preservatives, paint and pigments, textile steel fabrication and canning industries. These industries produce large quantities of toxic wastewater effluents ${ }^{2}$. The physical and chemical treatment of wastewater may involve one or more of the following: ion exchange $^{3}$, reverse osmosis ${ }^{4}$, electrolysis ${ }^{5}$, precipitation $^{6}$ and reduction ${ }^{7}$. Unfortunately, these methods are expensive and require the use of contaminating products for desorption of metals for cleaning up of the inorganic matrix. Physico-chemical methods presently in use have several disadvantages such as unpredictable metal ion removal, high reagent requirements and formation of sludge and its disposal, in addition to high installation and operational costs ${ }^{8}$.

Recently there has been a trend towards the use of biological materials such as fungi, bacteria, yeasts and algae as new sampling and sample clean up approaches ${ }^{9,10}$. Although most organisms have detoxification abilities (i.e. mineralization, transformation and immobilization of pollutants), play a crucial role in biogeochemical cycles and in sustainable development of biosphere. The use of microbial cells as biosorbents for heavy metals offers a potentially inexpensive alternative compared to conventional methods of heavy metal decontamination from variety of industrial aqueous process streams ${ }^{11}$. Baker's yeast, Saccharomyces cerevisiae has been reported to show good sorption characteristics for several metals and its potential utility for bioremediation is acknowledged $^{12-21}$.

Recently, Mapolelo and Torto have reported the use of Baker's yeast for trace metal enrichment of metal ions in aquatic environments ${ }^{21}$. However, in order to realize practical application, such studies need further evaluation of time required for sorption as well as other parameters that affect the rate of biotransformation processes. Therefore the present study evaluates a mechanistic approach of bioreduction of toxic heavy metal ions like $\mathrm{Co}^{++}, \mathrm{Ni}^{++}$, $\mathrm{Cu}^{++}$and $\mathrm{Cd}^{++}$by Saccharomyces cerevisiae suspended in aqueous solution and the factors affecting the biotransformation. The effect of $\mathrm{pH}$, water hardness and biomass dose proved to be important for the trace metal ion enrichment process and biotransformation as well.

\section{Experimental}

\section{Materials and methods}

Cadmium (II) nitrate, cobalt (II) sulphate, nickel (II) sulphate, copper (II) sulphate and zinc (II) sulphate, calcium chloride, acetic acid, sodium acetate, dextrose and chloroform were obtained from s.d. fine, Mumbai, INDIA, as analytical reagent grade materials and were used without further purification. 8-hydroxy quinoline and diethyl thio carbamate were purchased from Aldrich. All dilute solutions were prepared in double-distilled water, with specific conductance equal to $(1.3 \pm 0.1) \mu \Omega^{-1} \mathrm{~cm}^{-1}$. Stock solutions of $\mathrm{Cd}^{++}, \mathrm{Co}^{++}, \mathrm{Ni}^{++}$, and $\mathrm{Cu}^{++}$ of $0.1 \mathrm{mM}$ were prepared. For standardization of EDTA, $0.1 \mathrm{mM}$ standard $\mathrm{ZnSO}_{4}$ solution was prepared. Local brand active dry Bakers yeast was purchased from a grocery shop.

\section{Instrumentation}

Spectronic 20 was used to determine concentration of unreacted $\mathrm{Cd}^{++}, \mathrm{Co}^{++}, \mathrm{Ni}^{++}$and $\mathrm{Cu}^{++}$by solvent extraction. All metal ions were abstracted from artificially prepared aqueous solution by known techniques of solvent extraction. All $\mathrm{pH}$ measurements were carried out with locally made digital $\mathrm{pH}$ meter. Incubation was carried out in incubator maintained at $25^{\circ} \mathrm{C}$. 


\section{Effect of $\mathrm{pH}$ on biotransformation}

$10 \mathrm{~mL}$ of $\mathrm{pH}$ adjusted $(\mathrm{pH} 3.0,4.0,5.0,6.0)$ metal solutions having $0.01 \mathrm{mM}$ metal ion concentration were added to the activated culture of $2.0 \mathrm{~g}$ of Saccharomyces cerevisiae in four separate centrifuge tubes and incubated at $25^{\circ} \mathrm{C}$ in incubator for 24 hours. Subsequently the solutions were centrifuged at $5300 \mathrm{~g}$ for 1 minute $10 \mathrm{~mL}$ of the clear supernatant liquid was separated from each centrifuge tube, diluted to $20 \mathrm{~mL}$ with deionised water. The unreacted metal ions were abstracted by 8-hydroxy quinoline / diethylthio carbamate in $\mathrm{CHCl}_{3}$ at different $\mathrm{pH}$ and further analyzed spectrophotometrically (Table 1 ). The procedure was repeated for the optimization of maximum metal ion biotransformation. The reaction conditions were optimized at $\mathrm{pH} 7.0$ with maximum out put of bioreduction. For $\mathrm{pH}$ adjustment, $1.0 \mathrm{mM}$ of $\mathrm{HCl}$ and $1.0 \mathrm{mM}$ of $\mathrm{NaOH}$ solutions were used.

Table 1. Bioreduction of toxic heavy metal ions by Saccharomyces cerevisiae

\begin{tabular}{cccccc}
\hline $\begin{array}{c}\text { Metal } \\
\text { ions }\end{array}$ & $\begin{array}{c}\text { Initial conc. } \\
\mathrm{mM}\end{array}$ & & $\begin{array}{c}\text { Ligand } \\
\text { in } \mathrm{CHCl}_{3}\end{array}$ & $\begin{array}{c}\text { Conc. of unreacted } \\
\text { metal ions in } \mathrm{mM} \\
10^{-3}\end{array}$ & $\begin{array}{c}\text { Total bioreduction } \\
\text { in \% moles }\end{array}$ \\
\hline $\mathrm{Co}^{++}$ & 0.01 & 3.6 & 8-Hydroxy Quinoline & 2.0 & 80 \\
$\mathrm{Cd}^{++}$ & 0.01 & 4.5 & 8-Hydroxy Quinoline & 3.7 & 63 \\
$\mathrm{Ni}^{++}$ & 0.01 & 3.5 & 8-Hydroxy Quinoline & 5.0 & 50 \\
$\mathrm{Cu}^{++}$ & 0.01 & 8.5 & Diethyl thio carbamate & 5.6 & 44 \\
\hline
\end{tabular}

\section{Effect of biomass}

Experiments were conducted to study the effect of biomass at $7.0 \mathrm{pH} .0 .5 \mathrm{~g}, 1.0 \mathrm{~g}, 2.0 \mathrm{~g}$ of dry Saccharomyces cerevisiae, $2.0 \mathrm{~g}$ of glucose and $3 \mathrm{~mL}$ of potassium dihydrogen phosphate buffer $(\mathrm{pH}=7.0,1.0 \mathrm{mM})$ in three separate centrifuge tubes were incubated for several minutes at $30^{\circ} \mathrm{C}$ till $\mathrm{CO}_{2}$ evolution ceased. To the activated culture of Sacchromycomyces cerevisiae, the metal ion solution was added in such a way that the strength of the solution became $10^{-2} \mathrm{mM}$. The procedure was repeated for each metal ion. In order to study the effect of biomass, three sets were prepared. In each set $0.5 \mathrm{~g}, 1.0 \mathrm{~g}, 2.0 \mathrm{~g}$ of dry Sacchromycomyces cerevisiae was added separately and put into a shaker at room temp ( $200 \mathrm{rpm})$. The reaction was carried out for a period of 24 hours.

\section{Effect of water hardness}

Anhydrous Calcium Chloride (0.0026, $0.0152,0.0270$ and $0.0366 \mathrm{~g})$ was added to $250 \mathrm{~mL}$ of 0.1 $\mathrm{mM} \mathrm{Co}{ }^{++}, \mathrm{Cd}^{++}, \mathrm{Ni}^{++}$and $\mathrm{Cu}^{++}$solutions separately in each flask. In each case the $\mathrm{pH}$ was adjusted to 7.0 to avoid introducing other potential interferent. $10 \mathrm{~mL}$ of $0.01 \mathrm{mM}$ metal ion solution was added to the activated culture of $2.0 \mathrm{~g}$ Saccharomyces cerevisiae-glucose solution.

The same sampling and analysis procedure described in preceding section was repeated.

\section{Results and Discussion}

\section{Effect of pH on biotransformation of metal ions (Figure 1.)}

The $\mathrm{pH}$ level is one of the most important parameters of biotransformation for metal ions from aqueous solution. Regarding Saccharomyces cerevisiae, its high content of ionizable groups such as carboxyl, phosphate, hydroxyl, sulphate and amino on the cell wall polysaccharides make it, at least in theory, liable to influence $\mathrm{pH}$ variations. For effective biotransformation, it was evident that at low $\mathrm{pH}\left(\mathrm{pH}_{\text {initial }}<7\right)$, the requirement of biomass was significantly increased. The optimal reaction conditions were set at $\mathrm{pH} 7$ with $2.0 \mathrm{~g}$ of biomass for effective bioreduction. After completion of reaction, the $\mathrm{pH}$ of reaction mixture was changed from 7 to 6.3 . 


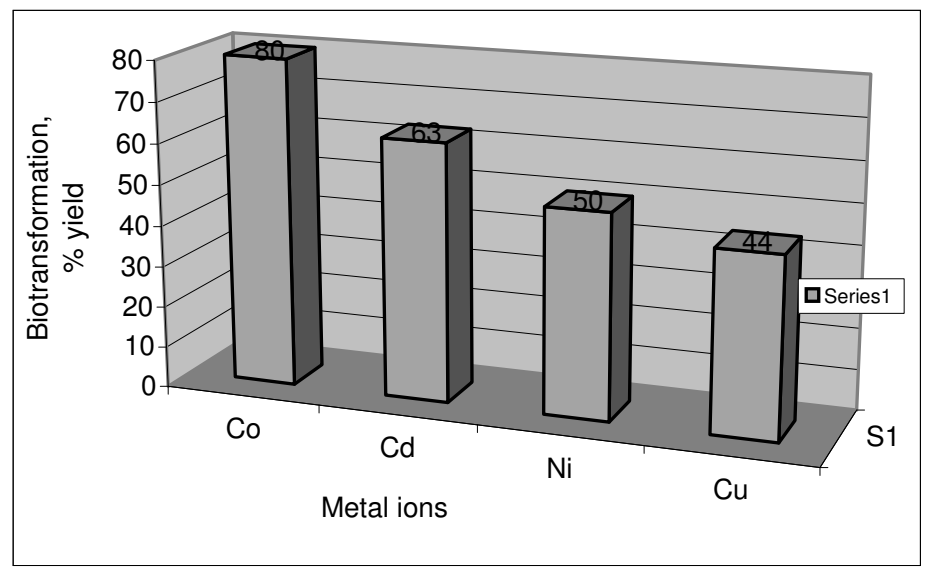

Figure 1. Effect of $\mathrm{pH}$ on biotransformation of metal ions Maximum biotransformation of heavy metal ions at $\mathrm{S} 1=\mathrm{pH}-7$

\section{Effect of biomass (Figure 2)}

Analysis of effect of biomass on conversion of metal ions to their metallic form revealed that: at $0.5 \mathrm{~g}$ of biomass, the conversion of $\mathrm{Co}^{++}, \mathrm{Cd}^{++}, \mathrm{Ni}^{++}$, and $\mathrm{Cu}^{++}$was $30 \%, 23.62 \%, 18.75 \%$, $16.5 \%$ respectively in their metallic forms. At $1.0 \mathrm{~g}$ of biomass, the conversion of $\mathrm{Co}^{++}, \mathrm{Cd}^{++}$, $\mathrm{Ni}^{++}$and $\mathrm{Cu}^{++}$was $50 \%, 39.37 \%, 31.25 \%$, and $27.5 \%$ respectively in their metallic forms. At $2.0 \mathrm{~g}$, maximum biotransformation was observed i.e. total conversion of $\mathrm{Co}^{++}, \mathrm{Cd}^{++}, \mathrm{Ni}^{++}, \mathrm{Cu}^{++}$ was $80 \%, 63 \%, 50 \%$, and $44 \%$ respectively in their metallic forms. Thus the reaction conditions optimized for maximum output were at $2.0 \mathrm{~g}$ of biomass with $\mathrm{pH} 7$.

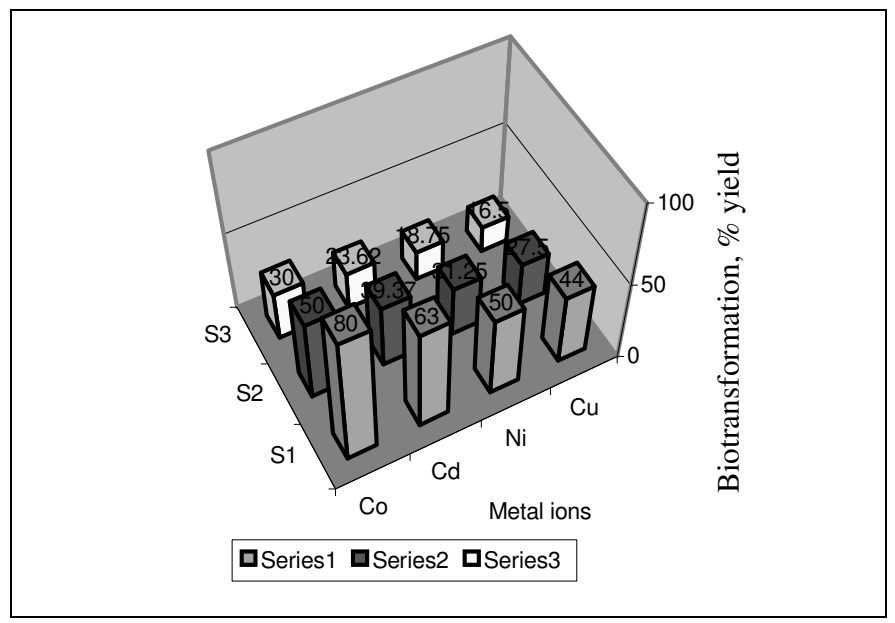

Figure 2. Effect of biomass

$\mathrm{S} 1=2.0 \mathrm{~g}, \mathrm{~S} 2=1.0 \mathrm{~g}, \mathrm{~S} 3=0.5 \mathrm{~g}$ of Saccharomyces cerevisiae

Effect of water hardness (Figure 3)

Experimental findings concerning the effect of water hardness evaluated that the rate of biotransformation of $\mathrm{Co}^{++}, \mathrm{Ni}^{++}, \mathrm{Cu}^{++}$, and $\mathrm{Cd}^{++}$ions to their metallic forms, in the presence of $\mathrm{Ca}^{++}$was strongly reduced as shown in Figure 3. 
- At 0.0026g of CaCO3: \% Conversion of $\mathrm{Co}^{++}, \mathrm{Ni}^{++}, \mathrm{Cu}^{++}$, and $\mathrm{Cd}^{++}$was $70,42,35$ and 54 respectively.

- At 0.0152g of CaCO3: \% Conversion of $\mathrm{Co}^{++}, \mathrm{Ni}^{++}, \mathrm{Cu}^{++}$, and $\mathrm{Cd}^{++}$was 50, 30, 25 and 38.57 respectively.

- At 0.0270g of CaCO3: \% Conversion of $\mathrm{Co}^{++}, \mathrm{Ni}^{++}, \mathrm{Cu}^{++}$, and $\mathrm{Cd}^{++}$was $26,12,10$ and 15.42 respectively.

- At 0.0366g of CaCO3: \% Conversion of $\mathrm{Co}^{++}, \mathrm{Ni}^{++}, \mathrm{Cu}^{++}$, and $\mathrm{Cd}^{++}$was $20,3,2.5$ and 3.85 respectively.

As water hardness increased from 9.45 to $133.09 \mathrm{mg}$ of $\mathrm{CaCO}_{3} / \mathrm{L}$, the rate of biotransformation decreased. This suggests that there is a competition between calcium ion and other toxic heavy metal ions for bioreduction, shows the contrast effect to heavy metal ion removal in solution. Though in this study, hardness showed contrast effect on bioreduction of $\mathrm{Co}^{++}, \mathrm{Ni}^{++}, \mathrm{Cu}^{++}$, and $\mathrm{Cd}^{++}$and retarded the rate of biotransformation but evidently this technology also reduced the hardness through $\mathrm{Ca}^{++}$reduction.

$\mathrm{BOD}, \mathrm{COD} \& \mathrm{SO}_{4}$

BOD and COD results were increased significantly. $\mathrm{SO}_{4}{ }^{-2}$ concentration was also reduced.

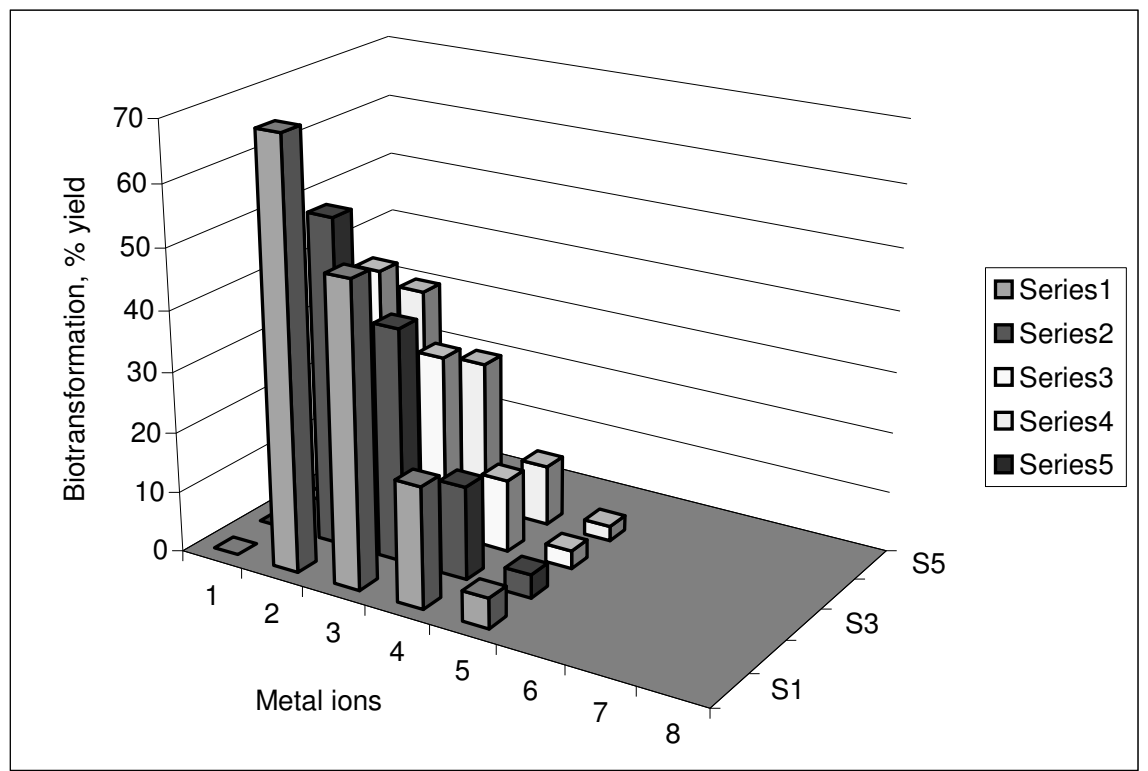

Figure 3. Effect of water hardness

$\mathrm{S} 1=0.0026 \mathrm{~g}$ of $\mathrm{CaCO}_{3}, \quad 2=\mathrm{Co}^{++}$

$\mathrm{S} 2=0.0152 \mathrm{~g}$ of $\mathrm{CaCO}_{3}, \quad 3=\mathrm{Cd}^{++}$

$\mathrm{S} 3=0.0270 \mathrm{~g}$ of $\mathrm{CaCO}_{3}, \quad 4=\mathrm{Ni}^{++}$

$\mathrm{S} 4=0.0366 \mathrm{~g}$ of $\mathrm{CaCO}_{3}, \quad 5=\mathrm{Cu}^{++}$

\section{Conclusion}

From the inferred results the following conclusions can be drawn.

- The biomass concentrations, $\mathrm{pH}$ of the reaction mixture and water hardness influence the rate of bioreduction of $\mathrm{Co}^{++}, \mathrm{Cd}^{++}, \mathrm{Ni}^{++}$and $\mathrm{Cu}^{++}$to their respective metallic forms. 
- This eco-friendly technique can be scaled for the treatment of metal containing effluent from various industrial establishments, thus preventing the release of hazardous metal ions to water bodies, which can otherwise lead to poisoning of aquatic as well as human life.

- The illustrated technique provides a fruitful area of study on removal of other inorganic and organic impurities from wastewater using Saccharomyces cerevisiae as biocatalyst.

Similarly it was evident that the metallic forms were adsorbed on to cell wall of the fungi. Hence the technique is very much important in development of nano particles of metals, which would be useful in bioremediation of wastewater, after recycling and sufficient aeration of water it can be reused.

\section{References}

1. Martins B L, Cruz C C V, Luna A S and Henriques C A, Biochem Eng J., 2006, 27(3), 310-314.

2. Raji C and Anirudhan T S, Indian J Chem Technol., 1997, 4, 228-236.

3. Cruz C C V, da Costa A C A, Henriques C A and Luna A S, Biomass Bioresour Technol., 2004, 91, 249-257.

4. Qdais S, Desalination, 2004, 164(2), 105-110.

5. Fischer R, Siedel H, Morgenstern P, Forster H J, Theele W and Krebs R, Eng Life Sci., 2005, 5(2), 163-168.

6. Banfalvi G, Chemosphere, 2006, 63(7), 1231-1234.

7. Volesky B, In Volesky B, Ed., Bioabsorbents and biosorption of heavy metals CRC Press, Boca Raton, FL, 1990, 221-238.

8. Deepa, Satishkumar K K M, Binupriya A R, Murugesan G S, Swaminathan K and Yun S E, Chemosphere, 2006, 62(5), 833-840.

9. Vasudevan P, Padmavathy V, Tewari N and S. C. Dhingra, J Sci Ind Res., 2001, 60, 112-120.

10. Volesky B and May-Phillips H A, Appl Microbiol Biotechnol., 1995, 42, 797-806.

11. Khoo K M and Ting Y P, Biochem Eng J., 2001, 8, 51-59.

12. Vasudevan P, Padmavathy V and Dhingara S C, Bioresour Technol., 2002, 82, 285-9.

13. Simmon P and Singleton I, Appl Microbiol., 1996, 45, 278-85.

14. Omar N B, Merroum M L, Gonzalea-Munoz M T and Arias J M, J Appl Bacteriol., 1996, 81, 283-7.

15. Vasudevan P, Padmavathy V and Dhingara S C, Bioresour Technol., 2003, 89, 218-287.

16. Loukidou M X, Zouboulis A I, Karapantsios T D and Matis K A, Physicochem Eng Aspects., 2004, 242, 93-104.

17. Schmuhl R and Krieg H M K, Water SA, 2001, 27, 1-7.

18. Neide E, Carriilho V M and Gilbert T R, J Environ Monit., 2000, 2, 410-415.

19. Volesky B, FEMS Microbiol Rev., 1994, 14, 291-302.

20. Junghams K and Strauke G, Biol Mat., 1994, 4, 233-7.

21. Mapolelo M and Torto N, Talanta, 2004, 64, 39-47. 


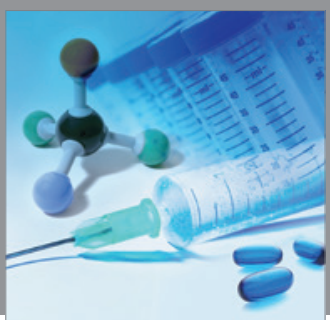

International Journal of

Medicinal Chemistry

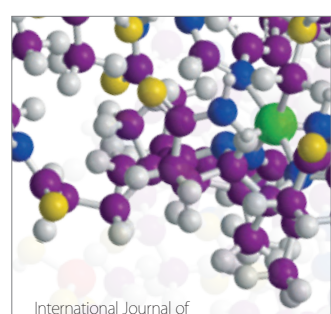

Carbohydrate Chemistry

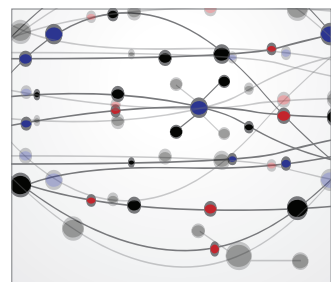

The Scientific World Journal
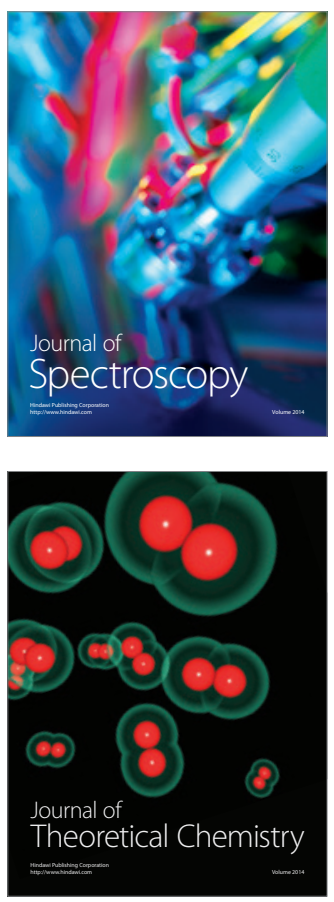
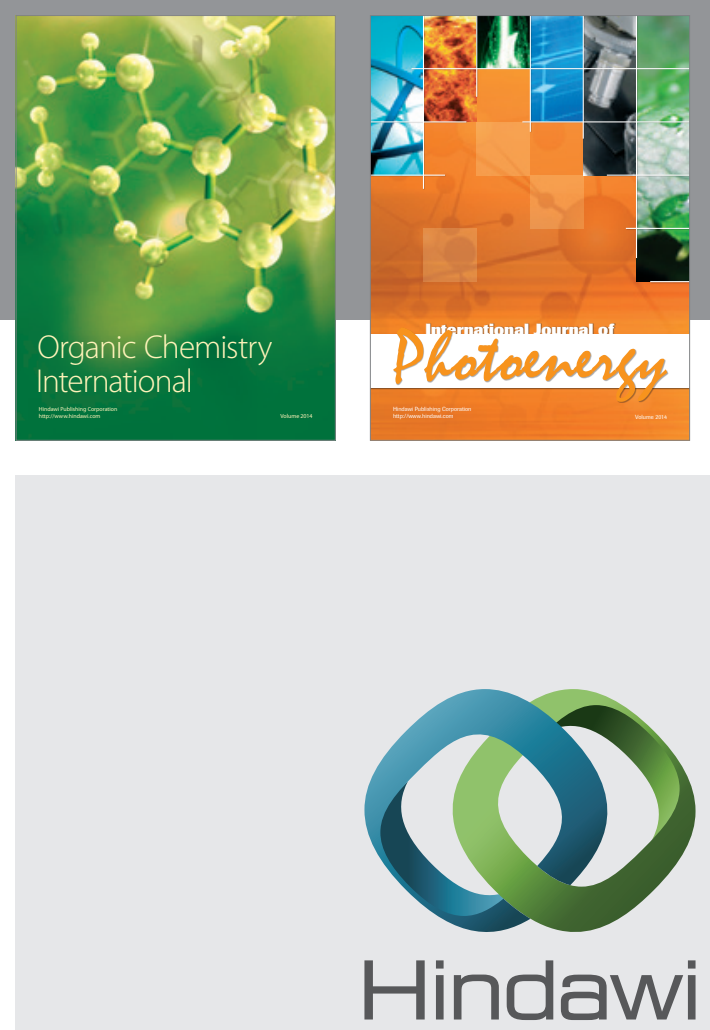

Submit your manuscripts at

http://www.hindawi.com
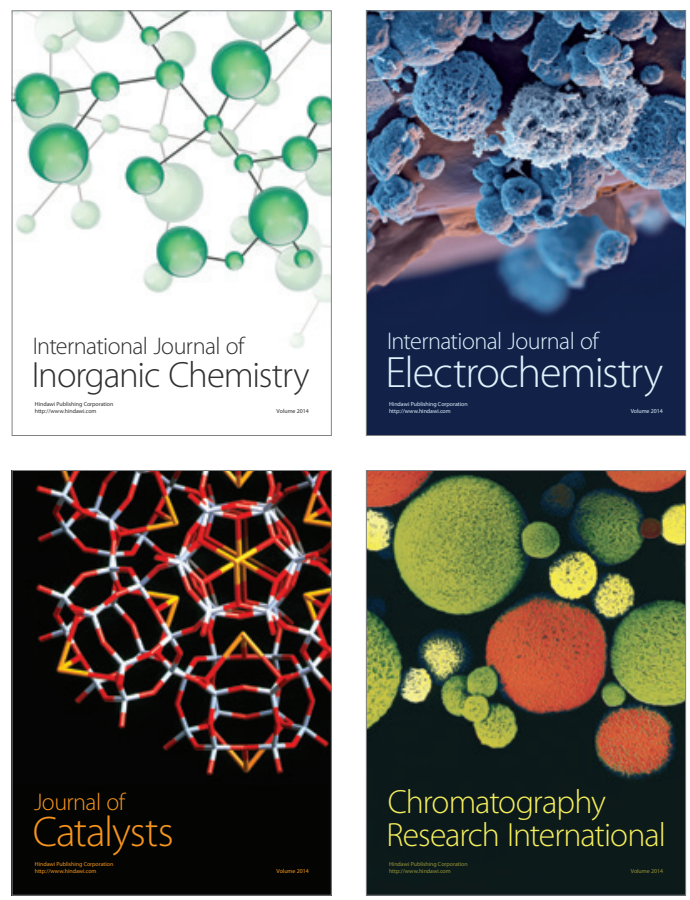
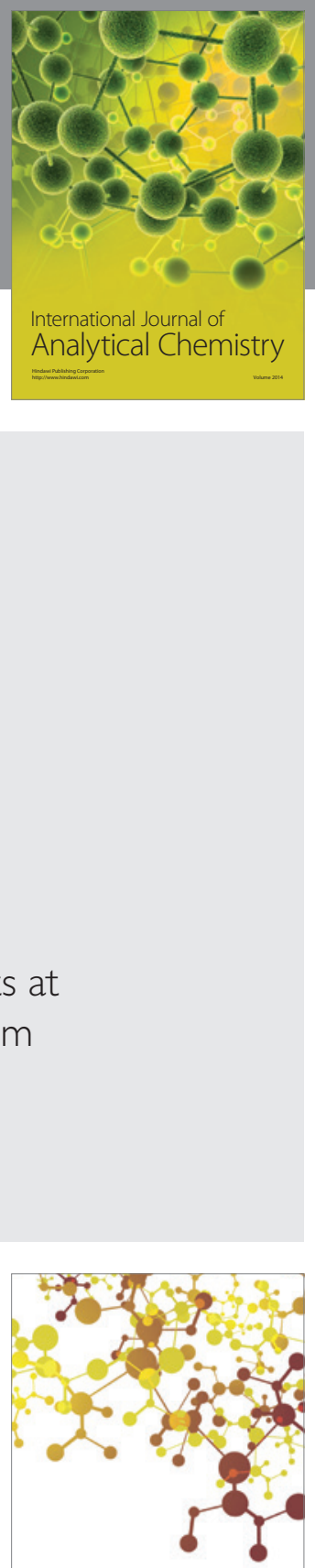

Journal of

Applied Chemistry
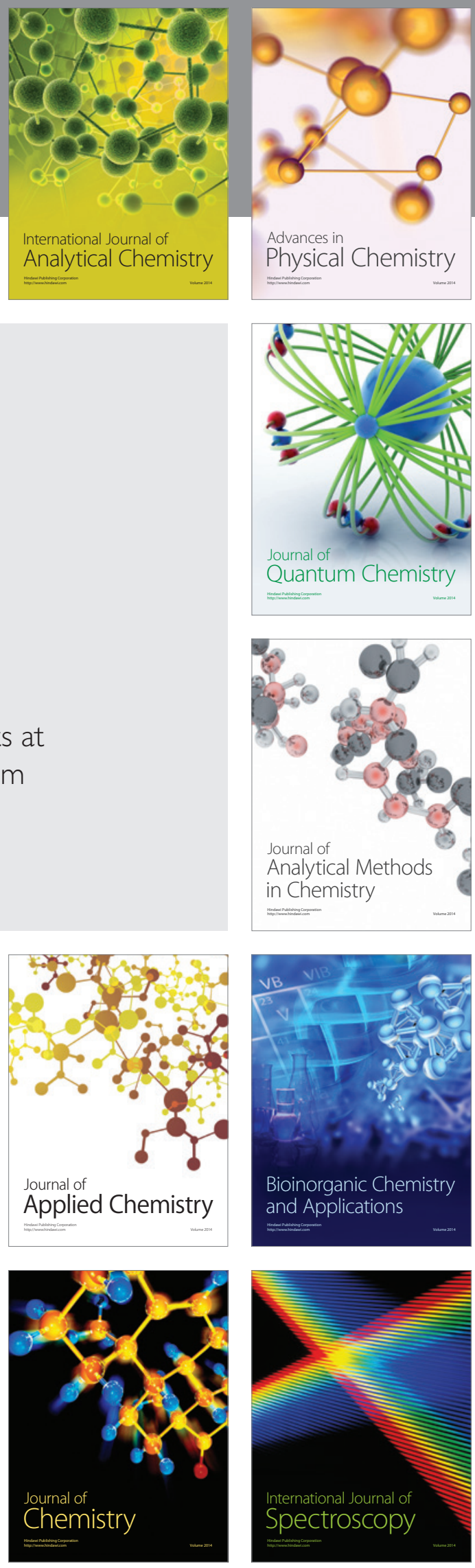